\title{
Pengaruh pendapatan asli daerah dan dana perimbangan terhadap belanja langsung dan belanja tidak langsung serta pertumbuhan ekonomi di indonesia
}

\author{
Yulianus Lisa ${ }^{1}$, Priyagus ${ }^{2}$ \\ Fakultas Ekonomi dan Bisnis Universitas Mulawarman, Samarinda \\ ${ }^{1}$ Email: yulianus.lisa@mhs.feb.unmul.ac.id \\ ²Email: priyagus@feb.unmul.ac.id
}

\begin{abstract}
Abstrak
Tujuan dari penelitian ini dilakukan adalah untuk menganalisis Pengaruh Pendapatan Asli Daerah Dan Dana Perimbangan Terhadap Belanja Langsung Dan Belanja Tidak Langsung Serta Pertumbuhan Ekonomi di Indonesia. Variabel dalam penelitian ini adalah PAD dan Dana Perimbangan Sebagai Variabel Dependen, Belanja Langsung dan Belanja Tidak Langsung serta Pertumbuhan Ekonomi sebagai Variabel Independen. Jumlah sampel adalah 33 Provinsi di Indonesia dari tahun 2009 sampai dengan tahun 2013. Hasil riset ini menunjukkan bahwa PAD dan Dana Perimbangan berpengaruh positif dan signifikan terhadap Belanja Langsung dan Belanja Tidak Langsung. PAD dan Dana Perimbangan berpengaruh negatif terhadap pertumbuhan ekonomi melalui Belanja Langsung dan berpengaruh positif dan signifikan terhadap pertumbuhan ekonomi melalui Belanja Tidak Langsung.
\end{abstract}

Kata Kunci: Pendapatan asli daerah; dana perimbangan; belanja langsung

\section{The effect of original regional income and balancing funds on direct spending and indirect shopping and economic growth in indonesia}

\begin{abstract}
The aim of this research is to analyze the influence of Local Revenue and Fiscal Balance Transfers on the Direct and Indirect Expenditures as well as on the Economic Development in Indonesia. The variables in this research were Local Revenue and Fiscal Balance Transfers as independent variables whereas Direct, Indirect Expenditures and Economic Developments were the dependent variables. The sample included 33 provinces in Indonesia over the period of 2009 to 2013. The research findings indicated that the Local Revenue and Fiscal Balance Transfers had a positive and significant influence on the Direct and Indirect Expenditures. In addition, Local Revenue and Fiscal Balance Transfers had a negative influence on the economic development through Direct Expenditure and had a positive, significant influence on the economic development through the Indirect Expenditure.
\end{abstract}

Keywords: Local revenue; fiscal Balance; transfers on the direct 


\section{PENDAHULUAN}

Pertumbuhan ekonomi yang pesat merupakan fenomena yang penting dialami dunia hanya semenjak abad dua belakangan ini. Dalam periode tersebut dunia telah mengalami perubahan yang sangat nyata apabila dibandingkan dengan periode sebelumnya. Sampai ke abad -18 kebanyakan masyarakat diberbagai negara masih hidup dalam taraf subsisten dan mata pencarian utamanya adalah dari melakukan kegiatan di sektor pertanian, perikanan atau berburu. (Sukirno,2013:421)

Ditinjau dari segi sudut ekonomi, perkembangan ekonomi dunia yang berlaku semenjak dua abad yang lalu menimbulkan dua efek penting yang sangat menggalakkan yaitu kemakmuran dan taraf hidup masyarakat makin meningkat dan dapat menciptakan kesempatan kerja yang baru kepada penduduk yang terus bertambah jumlahnya.

Dalam kegiatan perekonomian yang sebenarnya pertumbuhan ekonomi berarti perkembangan fiskal produksi barang dan jasa, yang berlaku di suatu negara, seperti pertambahan jumlah produksi barang industri, perkembangan infrastruktur, pertambahn jumlah sekolah, pertambahan produksi sektor jasa dan pertambahan produksi modal. Tetapi dengan menggunakan berbagai jenis data adalah sangat sukar untuk memberi gambaran tentang pertumbuhan ekonomi yang dicapai.

Peningkatan ini didukung oleh penerimaan pajak daerah. Peran kedua terbesar setelah pajak daerah yaitu dari lain-lain PAD yang sah, kemudian pengelolaan kekayaan daerah yang dipisahkan, dan retribusi daerah. Pada tahun 2013, PAD ditargetkan naik menjadi 92,45 triliun rupiah, dimana penerimaan pajak ditargetkan tetap meningkat walaupun tidak terlalu tinggi.

Berdasarkan fenomena yang telah dipaparkan diatas, maka peneliti tertarik untuk meneliti pengaruh Pendapatan Asli Daerah dan Dana Perimbangan terhadap Belanja Langsung dan Belanja Tidak Langsung serta pertumbuhan ekonomi di Indonesia.

\section{TINJAUAN PUSTAKA}

\section{Penelitian Terdahulu}

Beberapa peneliti terdahulu telah banyak melakukan penelitian ini, diantaranya penelitian yang dilakukan oleh I Gede Dwi Purnama Putra (2012) dengan judul Pengaruh belanja langsung dan belanja tidak langsung Terhadap pertumbuhan ekonomi menemukan bahwa belanja langsung dan belanja tidak langsung memilikl pengaruh signifikan terhadap pertumbuhan ekonomi/PDRB kabupaten Badung. Penelitian lain dilakukan oleh Akhmad Imam Amrozi (2013) tentang Pengaruh Dana Alokasi Umum (Dau) Dan Pendapatan Asli Daerah (Pad) Terhadap Alokasi Belanja Pemerintah Daerah seluruh kabupaten/kota di indonesia, melalui hasil pengujian dapat disimpulkan bahwa DAU dan PAD berpengaruh positif terhadap alokasi belanja pegawai tetapi tidak kepada belanja modal pemerintah daerah, yang mana pada hasil penelitian ini berpengaruh negatif, yang berarti semakin besar pendapatan yang diterima pemerintah daerah (DAU dan PAD) maka semakin turun Belanja Modal.

\section{METODE PENELITIAN}

\section{Rancangan Penelitian}

1. Penelitian ini menggunakan data pooling, yaitu kombinasi antara data rentan waktu (time series) dan silang tempat (cross section) dan populasi yang akan digunakan di dalam penelitian ini adalah seluruh Provinsi di indonesia yang berjumlah 33 Provinsi. Penelitian ini memiliki rentang waktu 5 tahun, yaitu tahun 2009 sampai dengan 2013, sehingga jumlah amatan berjumlah 33 Provinsi x 5 tahun = 165 sampel.

2. Dalam penelitian ini penulis ingin mengetahui sejauh mana Pendapatan Asli Daerah dan Dana Perimbangan mempengaruhi Belanja Lansung dan Belanja Tidak Langsung serta pengaruhnya terhadap pertumbuhan ekonomi. Dengan demikian untuk menganalisa pengaruh dari setiap variabel, maka model yang digunakan adalah analisis jalur (path analysis).

\section{Analisis Data}

Dalam menganalisa data digunakan teknik analisa jalur (path analysis) dalam menguji besarnya pengaruh yang ditunjukkan oleh koefisien jalur pada setiap diagram jalur dari hubungan kausal antara 
variabel Pendapatan Asli Daerah dan Dana Perimbagan terhadap Belenja Langsung dan Belanja Tidak Langsung serta dampaknya terhadap pertumbuhan ekonomi.

\section{HASIL DAN PEMBAHASAN}

Berdasarkan informasi dari data yang telah dikumpulkan dari berbagai sumber seperti Badan Pusat Statistik, maka dapat dilakukan analisis untuk menjawab perumusan masalah yang telah disusun pada bab sebelumnya.

\section{Persamaan Sub Struktur 1}

Dari hasil uji $\mathrm{F}$ pada tabel 5.4. ANOVA ${ }^{\mathrm{b}}$ Model Sub Struktur -1 nilai signifikansinya $<0,05$ $(0,000<0,05)$ sedangkan $\mathrm{F}$ tabel $=487,505 ; \mathrm{F}$ hitung $=2,27$ artinya $(\mathrm{F}$ table $>\mathrm{F}$ hitung $)$ maka Ho ditolak, Ha diterima sehingga dapat diambil kesimpulan maka secara simultan variabel independen ( Total PAD dan Total Dana Perimbangan) berpengaruh secara signifikan terhadap variabel independen (Total Belanja Langsung).

\section{Uji t}

Uji t (parsial) adalah untuk melihat pengaruh variabel-variabel independen secara parsial terhadap variabel dependen. Dari hasil pengujian SPSS maka nilai uji t adalah sebagai berikut :

Berdasarkan hasil uji t pada Tabel 5.2 maka secara parsial pengaruh masing-masing variabel independen terhadap variabel dependen dapat diuraikan sebagai berikut :

1. Nilai signifikansi X1 (Total PAD) $=0.000<0.05$. Artinya nilai signifikansi $<0.05$ sehingga Ho ditolak Ha diterima maka ada pengaruh signifikan secara parsial antara X1 (Total PAD) terhadap Belanja Langsung (Total Belanja Langsung).

2. Nilai signifikansi $X 2$ (Total Dana Perimbangan) $=0.000<0.05$. Artinya nilai signifikansi $<0.05$ sehingga Ho ditolak Ha diterima maka ada pengaruh signifikan secara parsial antara X12 (Total Dana Perimbangan) terhadap Belanja Langsung (Total Belanja Langsung).

Dari uji t diatas maka,

$\mathrm{X} 1$ : $\mathrm{t}$ hitung $=4,579, \mathrm{t}$ tabel $=1,975$ maka Ho ditolak Ha diterima artinya PAD berpengaruh signifikan terhadap Belanja Langsung

$\mathrm{X} 2$ : $\mathrm{t}$ hitung $=17,446, \mathrm{t}$ tabel $=1,975$ maka Ho ditolak Ha diterima artinya Dana Perimbangan berpengaruh signifikan terhadap Belanja Langsung.

Dari uraian di atas maka dengan demikian dapat disusun persamaan regresi Sub Struktur - 1 sebagai berikut :

$$
\mathrm{Y} 1=0,201 \mathrm{X} 1+0,767 \mathrm{X} 2+\mathrm{e}
$$

Besarnya koefisien diterminan $\mathrm{R}_{\text {square }}=0,858=85,8 \%$ (Tabel 5.2 Model summary ${ }^{b}$ ) dan besarnya pengaruh variabel lain diluar model yaitu, $\rho_{y e 1}=1-0,858=0,142=14,2 \%$.

\section{Pengaruh Pendapatn Asli Daerah (PAD) terhadap Belanja Langsung.}

Dari tabel Coefficients ${ }^{a}$ diperoleh nilai statistik $t$ untuk variabel PAD sebesar 0,201 dengan nilai probabilitas (sig.) $=0,000$. Karena nilai sig. $<0,05$ maka hipotesis diterima pada tingkat kepercayaan 95 persen, artinya dalam penelitian ini PAD berpengaruh positif dan signifikan terhadap Belanja Langsung pada tingkat kepercayaan 5 persen.

\section{Pengaruh Dana Perimbangan terhadap Belanja Langsung.}

Dari tabel Coefficients ${ }^{a}$ diperoleh nilai statistik $t$ untuk variabel derajat Dana Perimbangan sebesar 0,767 dengan nilai probabilitas (sig.) $=0,00$. Karena nilai sig. $<0,05$ maka hipotesis diterima, artinya dalam penelitian ini, Dana Perimbangan secara individu berpengaruh Positif dan signifikan terhadap Belanja Langsung. 


\section{Persamaan Sub Struktur 2.}

Nilai signifikansi X1 $($ Total PAD $)=0.000<0.05$. Artinya nilai signifikansi $<0.05$ sehingga Ho ditolak Ha diterima maka ada pengaruh signifikan secara parsial antara X1 (Total PAD) terhadap Y2 Langsung (Total Belanja Tidak Langsung).

Nilai signifikansi X2 (Total Dana Perimbangan) $=0.000<0.05$. Artinya nilai signifikansi $<0.05$ sehingga Ho ditolak Ha diterima maka ada pengaruh signifikan secara parsial antara X2 (Total Dana Perimbangan) terhadap Y2 (Total Belanja Tidak Langsung).

Dari uji t diatas maka,

$\mathrm{X} 1$ : $\mathrm{t}$ hitung $=11,535, \mathrm{t}$ tabel $=1,975$ maka Ho ditolak Ha diterima artinya PAD berpengaruh signifikan terhadap Belanja Tidak Langsung

$\mathrm{X} 2$ : $\mathrm{t}$ hitung $=9,412, \mathrm{t}$ tabel $=1,975$ maka Ho ditolak Ha diterima artinya Dana Perimbangan berpengaruh signifikan terhadap Tidak Belanja Langsung.

Dari uraian di atas maka dengan demikian dapat disusun persamaan regresi Sub Struktur 2 sebagai berikut :

$$
\mathrm{Y} 2=0,540 \mathrm{X} 1+0,441 \mathrm{X} 2+\mathrm{e}
$$

Besarnya koefisien diterminan $\mathrm{R}$ square $=0,838=85,8 \%$ (Tabel 5.6 Model summary $\left.{ }^{b}\right)$ dan besarnya pengaruh variabel lain diluar model yaitu, $\rho_{y e 1}=1-0,838=0,162=16,2 \%$.

\section{Pengaruh PAD terhadap Belanja Tidak Langsung.}

Dari tabel Coefficients $^{a}$ diperoleh nilai statistik $t$ untuk variabel PAD sebesar 11,535 dengan nilai probabilitas (sig.) $=0,000$. Karena nilai sig. $<0,05$ maka hipotesis diterima pada tingkat kepercayaan 95 persen, artinya dalam penelitian ini PAD berpengaruh positif dan signifikan pada tingkat kepercayaan 5 persen terhadap Belanja Tidak Langsung

\section{Pengaruh Dana Perimbangan terhadap Belanja Tidak Langsung.}

Dari tabel Coefficients ${ }^{a}$ diperoleh nilai statistik $t$ untuk variabel derajat Dana Perimbangan sebesar 9,412 dengan nilai probabilitas (sig.) = 0,00. Karena nilai sig. $<0,05$ maka hipotesis diterima, artinya dalam penelitian ini, Dana Perimbangan secara individu berpengaruh Positif dan signifikan terhadap Belanja Tidak Langsung.

\section{Persamaan Sub Struktur 3.}

a) Nilai signifikansi Y1 (Total Belanja Langsung) $=0,038<0.05$. Artinya nilai signifikansi $<0.05$ sehingga Ho ditolak Ha diterima maka ada pengaruh signifikan secara parsial antara Y1 (Total Belanja Langsung) terhadap Y3 (Total Pertumbuhan Ekonomi).

b) Nilai signifikansi Y2 (Total Belanja Tidak Langsung) $=0,491>0.05$. Artinya nilai signifikansi > 0.05 sehingga Ho diterima, Ha ditolak maka berpengaruh tidak signifikan secara parsial antara Y2 (Total Belanja Tidak Langsung) terhadap Y3 (Total Pertumbuhan Ekonomi).

Dari uji t diatas maka:

$\mathrm{X} 1$ : $\mathrm{t}$ hitung $=-2,092, \mathrm{t}$ tabel $=1,975$ maka Ho ditolak, Ha diterima artinya Belanja Langsung berpengaruh Negatif dan signifikan terhadap Pertumbuhan Ekonomi

$\mathrm{X} 2$ : $\mathrm{t}$ hitung $=0,690, \mathrm{t}$ tabel $=1,975$ maka Ho diterima, Ha ditolak artinya Belanja Tidak Langsung berpengaruh positif dan tidak signifikan terhadap Pertumbuhan Ekonomi.

Dari uraian di atas maka dengan demikian dapat disusun persamaan regresi Sub Struktur 3 sebagai berikut:

$$
\mathrm{Y3}=0,198 \mathrm{Y} 1+0,694 \mathrm{Y} 2+\mathrm{e}
$$

Besarnya koefisien diterminan $\mathrm{R}_{\text {square }}=0,05=5,5 \%$ (Tabel 5.10 Model summary $\left.{ }^{b}\right)$ dan besarnya pengaruh variabel lain diluar model yaitu, $\rho_{y e 1}=1-0,05=0,95=95,0 \%$.

\section{Pengaruh Belanja Langsung terhadap Pertumbuhan Ekonomi.}

Dari tabel Coefficients ${ }^{a}$ diperoleh nilai statistik $t$ untuk variabel Belanja Langsung sebesar 0,092 dengan nilai probabilitas (sig.) $=0,038$. Karena nilai sig. $<0,05$ maka hipotesis diterima, 
artinya dalam penelitian ini Belanja Langsung berpengaruh Negatif dan signifikan terhadap Pertumbuhan Ekonomi pada tingkat kepercayaan 95 persen.

\section{Belanja Tidak Langsung berpengaruh terhadap Pertumbuhan Ekonomi.}

Dari tabel Coefficients ${ }^{a}$ diperoleh nilai statistik $t$ untuk variabel derajat Belanja Tidak Langsung sebesar 0,690 dengan nilai probabilitas (sig.) $\quad=0,491$. Karena nilai sig. $>0,05$ maka hipotesis ditolak, artinya dalam penelitian ini, Belanja Tidak Langsung secara individu berpengaruh tidak signifikan dan positif terhadap Pertumbuhan Ekonomi.

Model persamaan regresi sub struktur 1, sub struktur 2 dan sub struktur 3 yang telah distandarkan, dapat diperoleh model persamaan regresi dengan koefisien jalur sebagai berikut:

$$
\begin{aligned}
& \mathrm{Y} 1=0,201 \mathrm{X} 1+0,767 \mathrm{X} 2+\mathrm{e} \\
& \mathrm{Y} 2=0,540 \mathrm{X} 1+\mathbf{0 , 4 4 1} \mathrm{X} 2+\mathrm{e} \\
& \mathrm{Y} 3=0,198 Y 1+0,694 \mathrm{Y} 2+\mathrm{e}
\end{aligned}
$$

Kemudian dari hasil analisis tersebut akan dirangkum dalam bentuk dekomposisi dari koefisien jalur, sehingga dapat dilihat pengaruh langsung, pengaruh tak langsung dan total pengaruh masingmasing variabel bebas terhadap variabel tak bebasnya, seperti dalam tabel berikut:

Tabel 1. Dekomposisi Koefisien Jalur Model Lengkap

\begin{tabular}{clcccc}
\hline No & Hubungan & $\begin{array}{c}\text { Pengaruh } \\
\text { Langsung }\end{array}$ & $\begin{array}{c}\text { Melalui } \\
\text { Y1 }\end{array}$ & $\begin{array}{c}\text { Melalui } \\
\text { Y2 }\end{array}$ & $\begin{array}{c}\text { Pengaruh } \\
\text { Total }\end{array}$ \\
\hline 1 & X1 - Y1 & 0,201 & & & 0,201 \\
2 & X2 - Y1 & 0,767 & & & 0,767 \\
3 & X1 - Y2 & 0,540 & & & 0,540 \\
4 & X2 - Y2 & 0,441 & & & 0,441 \\
5 & Y1 - Y3 & $-0,320$ & & & $-0,320$ \\
6 & Y2 - Y3 & 0,106 & & & 0,106 \\
7 & X1 - Y3 & & $-0,064$ & 0,08 & 0,016 \\
8 & X2 - Y3 & & $-0,22$ & 0,047 & $-0,173$ \\
\hline
\end{tabular}

\section{Pembahasan}

\section{Pengaruh Pendapatan Asli Daerah (PAD) Terhadap Belanja Langsung}

Dari hasil uji statistik t diketahui bahwa Pendapatan Asli Daerah (PAD) berpengaruh positif dan signifikan terhadap Belanja Langsung. Artinya jika PAD di sebuah provinsi naik maka akan mengakibatkan kenaikan pada tingkat Belanja Langsung provinsi tersebut. Dari persamaan regresi berganda, diketahui bahwa PAD mempunyai koefisien positif sebesar 0,201. Artinya PAD memberikan pengaruh terhadap Belanja Langsung sebesar 20,1\%. Semakin tinggi PAD yang diperoleh sebuah provinsi maka tingkat Belanja Langsung provinsi tersebut akan meningkat. Hal ini sejalan dengan penelitian Indraingrum (2011) yang membahas tentang Pengaruh Pendapatan Asli Daerah (PAD) dan Dana Alokasi Umum (DAU) Terhadap Belanja Langsung (Studi Pada Pemerintah Daerah Kabupaten/Kota di Provinsi Jawa Tengah dan menemukan bahwa Pendapatan Asli Daerah berpengaruh positif dan signifikan terhasap belanja langsung.

\section{Pengaruh Dana Perimbangan Terhadap Belanja Langsung}

Berdasarkan uji statistik t diketahui bahwa Dana Perimbangan berpengaruh positif dan signifikan terhadap Belanja Langsung. Artinya peningkatan Dana Perimbangan mempengaruhi Belanja Langsung. Dari persamaan regresi linier berganda diketahui bahwa Dana Perimbangan memiliki koefisien positif sebesar 0,767.

Artinya Dana Perimbangan memberikan pengaruh sebesar 75,7\% terhadap Belanja Langsung sehingga dapat dikatakan Dana Perimbangan memberikan pengaruh yang signifikan dan positif terhadap Belanja Langsung. Hal ini sejalan dengan penelitian Lestari, Tri, (2010) yang membahas tentang Pengaruh Pendapatan Asli Daerah (PAD), Dana Alokasi Umum (DAU) dan Dana Bagi Hasil 
(DBH) Terhadap Belanja Langsung Pada Pemerintahan Kabupaten/Kota di Provinsi Jambi. Dan menemukan bahwa DAU, DBH berpengaru positif dan signifikan terhasap belanja Langsung.

\section{Pengaruh PAD Terhadap Belanja Tidak Langsung}

Dari hasil uji statistik t diketahui bahwa Pendapatan Asli Daerah (PAD) berpengaruh signifikan positif terhadap Belanja Tidak Langsung. Artinya jika PAD di sebuah provinsi naik maka akan mengakibatkan kenaikan pada tingkat Belanja Langsung provinsi tersebut. Dari persamaan regresi berganda, diketahui bahwa PAD mempunyai koefisien positif sebesar 0,540. Artinya PAD memberikan pengaruh terhadap Belanja Tidak Langsung sebesar 54,0\%, sehingga dapat dikatakan PAD memberikan pengaruh yang signifikan dan positif terhadap Belanja Tidak Langsung. Semakin tinggi PAD yang diperoleh sebuah provinsi maka tingkat Belanja Tidak Langsung provinsi tersebut akan meningkat. Hal ini sejalan dengan Akhmad Imam Amrozi (2013) yang membahas tentang Pengaruh Dana Alokasi Umum (DAU) dan Pendapatan Asli Daerah (PAD) Terhadap Alokasi Belanja Pemerintah Daerah di seluruh Kabupaten/Kota di Indonesia, menemukan bahwa PAD berpengaruh positif terhadap Belanja Pegawai.

\section{Pengaruh Dana Perimbangan terhadap Belanja Tidak Langsung}

Berdasarkan uji statistik t diketahui bahwa Dana Perimbangan berpengaruh positif dan signifikan terhadap Belanja Tidak Langsung. Artinya peningkatan Dana Perimbangan mempengaruhi Belanja Tidak Langsung. Dari persamaan analisis diketahui bahwa Dana Perimbangan memiliki koefisien positif sebesar 0,441. artinya Dana Perimbangan memberikan pengaruh sebesar 44,1\% terhadap Belanja Tidak Langsung sehingga dapat dikatakan Dana Perimbangan memberikan pengaruh yang signifikan dan positif terhadap Belanja Tidak Langsung. Hal ini sejalan dengan penelitian Mulya Zulfan (2016) yang membahas tentang Pengaruh Dana Alokasi Umum (DAU) Terhadap Belanja Langsung Dan Belanja Tidak Langsung Pada Kabupaten/Kota Di Aceh, menemukan bahwa variabel Dana Alokasi Umum berpengaruh positif terhadap Belanja Langsung sedangkan Belanja Tidak Langsung juga berpengaruh positif terhadap Dana Alokasi umum.

\section{Pengaruh Belanja Langsung Terhadap Pertumbuhan Ekonomi}

Berdasarkan uji statistik t diketahui bahwa Belanja Langsung berpengaruh negatif dan signifikan terhadap pertumbuhan ekonomi. Artinya peningkatan Belanja Langsung mempengaruhi Pertumbuhan Ekonomi. Dari hasil analisis diketahui bahwa Belanja Langsung memiliki koefisien Negatif sebesar $-0,320$ artinya Belanja Langsung memberikan pengaruh terhadap Pertumbuhan Ekonomi sebesar $\quad-0,320$ atau $-32,0 \%$, ini menandakan bahwa Belanja Langsung berperan dalam mempengaruhi pertumbuhan ekonomi akan tetapi arah yang berlawanan. Hal ini bermakna bahwa apabila terjadi penurunan terhadap belanja langsung maka akan menyebabkan penurunan pada capaian pertumbuhan ekonomi. Hal ini tidak sejalan dengan penelitian I Gede Dwi Purnama (2012) yang membahas tentang Pengaruh Belanja Langsung dan Belanja Tidak Langsung Terhadap Pertumbuhan Ekonomi di Kabupaten Bandung dan menemukan bahwa belanja langsung memilikl pengaruh positif signifikan terhadap pertumbuhan ekonomi/PDRB kabupaten Bandung.

\section{Pengaruh Belanja Tidak Langsung Terhadap Pertumbuhan Ekonomi}

Dari hasil uji statistik t diketahui bahwa Belanja Tidak Langsung berpengaruh positif dan tidak signifikan terhadap pertumbuhan ekonomi. Artinya peningkatan Belanja Tidak Langsung tidak memberikan pengaruh terhadap pertumbuhan ekonomi. Dari hasil analisis, Belanja Tidak Langsung mempunyai koefisien positif sebesar 0,106. artinya Belanja Tidak Langsung memberikan pengaruh sebesar 10,6 \% terhadap pertumbuhan ekonomi sehingga dapat dikatakan Belanja Tidak Langsung memberikan pengaruh yang positif dan tidak signifikan terhadap pertumbuhan ekonomi. Hal ini sejalan dengan penelitian I Gede Dwi Purnama (2012) yang membahas tentang Pengaruh Belanja Langsung dan Belanja Tidak Langsung Terhadap Pertumbuhan Ekonomi di Kabupaten Bandung dan menemukan bahwa belanja tidak langsung memilikl pengaruh positif dan signifikan terhadap pertumbuhan ekonomi/PDRB kabupaten Badung. 


\section{Pengaruh PAD Terdahap Pertumbuhan Ekonomi Melalui Belanja Langsung}

Dari hasil perhitungan didapatkan bahwa pengaruh PAD terhadap Pertumbuhan Ekonomi melalui Belanja Langsung adalah sebesar -0,064 artinya PAD berpengaruh negatif sebesar $-6,4 \%$ terhadap Pertumbuhan Ekonomi melalui Belanja Langsung. Artinya PAD berpengaruh negatif terhadap pertumbuhan ekonomi, ini disebabkan karena pengalokasian PAD terhadap Belanja Langsung dalam hal ini belanja modal lebih kecil dibanding dengan Belanja Tidak Langsung, sehingga Pertumbuhan Ekonomi mengalami penurunan. Hal ini tidak sesuai dengan hipotesis dalam penelitian ini.

\section{Pengaruh PAD Terdahap Pertumbuhan Ekonomi Melalui Belanja Tidak Langsung.}

Dari hasil perhitungan didapatkan bahwa pengaruh PAD terhadap Pertumbuhan Ekonomi melalui Belanja Tidak Langsung adalah sebesar 0,081 artinya PAD berpengaruh Positf sebesar 8,1\% terhadap Pertumbuhan Ekonomi melalui Belanja Tidak Langsung, ini disebabkan karena PAD yang terus meningkat, disamping itu dalam belanja tidak langsung, komponen yang cukup dominan adalah belanja pegawai. Pertumbuhan ekonomi selama ini masih di topang oleh konsumsi rumah tangga. Hal ini sesuai dengan hipotesis dalam penelitian ini.

\section{Pengaruh Dana Perimbangan Terdahap Pertumbuhan Ekonomi Melalui Belanja Langsung.}

Dari hasil perhitungan didapatkan bahwa pengaruh Dana Perimbangan terhadap Pertumbuhan Ekonomi melalui Belanja Langsung adalah sebesar -0,17 artinya Dana Perimbangan berpengaruh negatif terhadap pertumbuhan ekonomi sebesar $-17 \%$, ini kemungkinan disebabkan karena pengelolaan APBD di berbagai daerah masih belum efektif. Hal itu antara lain ditunjukkan oleh alokasi belanja pegawai yang terus meningkat, sebaliknya porsi belanja modal untuk pembangunan daerah justru menurun, sehingga Pertumbuhan Ekonomi mengalami penurunan. Hal ini tidak sesuai dengan hipotesis dalam penelitian ini.

\section{Pengaruh Dana Perimbangan Terdahap Pertumbuhan Ekonomi Melalui Belanja Tidak Langsung.}

Dari hasil perhitungan didapatkan bahwa pengaruh tidak langsung Dana Perimbangan terhadap Pertumbuhan Ekonomi melalui Belanja Tidak Langsung adalah sebesar 0,047 . Hal ini diasumsikan bahwa semakin tinggi Dana Perimbangan maka pengalokasian terhadap Tidak Belanja Langsung juga semakin tinggi, artinya dana perimbangan memberikan pengaruh positif terhadap Pertumbuhan Ekonomi melalui Tidak Belanja Langsung, karena selama ini pertumbuhan ekonomi di topang oleh konsumsi konsumsi rumah tangga. Hali ini sesuai dengan hipotesis dalam penelitian ini.

\section{Pengaruh Total PAD Terdahap Pertumbuhan Ekonomi Melalui Belanja Langsung dan Belanja Tidak Langsung.}

Dari hasil perhitungan didapatkan bahwa pengaruh total Pendapatan Asli Daerah Terdahap Pertumbuhan Ekonomi Melalui Belanja Langsung dan Belanja Tidak Langsung adalah sebesar 0,017 atau sebesar 1,7\% artinya PAD berpengaruh Positif terhadap Pertumbuhan Ekonomi melalui belanja langsung dan belanja tidak langsung. Hali ini sesuai dengan hipotesis dalam penelitian ini.

\section{Pengaruh Total Dana Perimbangan Terdahap Pertumbuhan Ekonomi Melalui Belanja Langsung dan Belanja Tidak Langsung.}

Dari hasil perhitungan didapatkan bahwa pengaruh total Dana Perimbangan Terdahap Pertumbuhan Ekonomi Melalui Belanja Langsung dan Belanja Tidak Langsung adalah sebesar -0,126 atau sebesar $-12,6 \%$ artinya Dana Perimbangan berpengaruh Negatif terhadap Pertumbuhan Ekonomi melalui Belanja Langsung dan Belanja Tidak Langsung, ini disebabkan karena pengalokasian Belanja Tidak Langsung dalam hal ini belanja pegawai lebih besar dibandingkan dengan Belanja Langsung dalam hal ini belanja modal. Hali ini tidak sesuai dengan hipotesis dalam penelitian ini. 


\section{SIMPULAN}

Berdasarkan hasil analisis data dan pengujian hipotesis yang telah diuraikan pada bab sebelumnya, maka penulis mengambil kesimpulan mengenai Pengaruh PAD dan Dana Perimbangan terhadap Belanja Langsung dan Belanja Tidak Langsung serta Pertumbuhan Ekonomi adalah sebagai berikut :

1. Hasil pengujian sub Struktur -1 menunjukkan secara simultan dan parsial variabel PAD berpengaruh positif dan signifikan terhadap Belanja Langsung

2. Hasil pengujian sub Struktur -1 menunjukkan secara simultan dan parsial variabel Dana Perimbangan berpengaruh positif dan signifikan terhadap Belanja Langsung.

3. Hasil pengujian sub Struktur -2 menunjukkan secara simultan dan parsial variabel PAD berpengaruh positif dan signifikan terhadap Belanja Tidak Langsung.

4. Hasil pengujian sub Struktur -2 menunjukkan secara simultan dan parsial variabel Dana Perimbangan berpengaruh positif dan signifikan terhadap Belanja Tidak Langsung

5. Hasil pengujian sub Struktur -3 menunjukkan Belanja Lansung berpengaruh negatif dan signifikan terhadap Pertumbuhan Ekonomi, namum Belanja Tidak Langsung berpengaruh Tidak signifikan terhadap Pertumbuhan Ekonomi.

6. Hasil pengujian sub Struktur -3 menunjukkan bahwa Belanja Tidak Langsung berpengaruh positif dan tidak signifikan terhadap Pertumbuhan Ekonomi

7. Pengaruh PAD Terdahap Pertumbuhan Ekonomi Melalui Belanja Langsung

8. Dari hasil perhitungan didapatkan bahwa pengaruh PAD terhadap Pertumbuhan Ekonomi melalui Belanja Langsung adalah sebesar $\quad-0,064$ artinya PAD berpengaruh negatif terhadap Pertumbuhan Ekonomi melalui Belanja Langsung. Hal ini tidak sesuai dengan hipotesis dalam penelitian ini

9. Pengaruh PAD Terdahap Pertumbuhan Ekonomi Melalui Belanja Tidak Langsung

10. Dari hasil perhitungan didapatkan bahwa pengaruh PAD terhadap Pertumbuhan Ekonomi melalui Belanja Tidak Langsung adalah sebesar 0,081 artinya atau sebesar 8,1\%, PAD berpengaruh Positf terhadap Pertumbuhan Ekonomi melalui Belanja Tidak Langsung. Ini disebabkan karena PAD dari setiap daerah banyak digunakan untuk belanja pegawai, selama ini pertumbuhan ekonomi masih ditopang oleh konsumsi rumah tangga. Hal ini sesuai dengan hipotesis dalam penelitian ini

11. Pengaruh Dana Perimbangan Terdahap Pertumbuhan Ekonomi Melalui Belanja Langsung.

12. Dari hasil perhitungan didapatkan bahwa pengaruh Dana Perimbangan terhadap Pertumbuhan Ekonomi melalui Belanja Langsung adalah sebesar $-0,17$ artinya Dana Perimbangan Berpengaruh negatif terhadap Pertumbuhan Ekonomi melalui Belanja Langsung. Hal ini tidak sesuai dengan hipotesis dalam penelitian ini.

13. Pengaruh Dana Perimbangan Terdahap Pertumbuhan Ekonomi Melalui Belanja Tidak Langsung.

14. Dari hasil perhitungan didapatkan bahwa pengaruh tidak langsung Dana Perimbangan terhadap Pertumbuhan Ekonomi melalui Belanja Tidak Langsung adalah sebesar 0,047 artinya Dana Perimbangan berpengaruh positif terhadap Pertumbuhan Ekonomi melalui Belanja Tidak Langsung. Hali ini sesuai dengan hipotesis dalam penelitian ini.

15. Pengaruh Total PAD Terdahap Pertumbuhan Ekonomi Melalui Belanja Langsung dan Belanja Tidak Langsung.

16. Dari hasil perhitungan didapatkan bahwa pengaruh total Pendapatan Asli Daerah Terdahap Pertumbuhan Ekonomi Melalui Belanja Langsung dan Belanja Tidak Langsung adalah sebesar 0,016 artinya PAD berpengaru Positif terhadap Pertumbuhan Ekonomi melalui belanja langsung dan belanja tidak langsung. Hali ini sesuai dengan hipotesis dalam penelitian ini.

17. Pengaruh Dana Perimbangan Terdahap Pertumbuhan Ekonomi Melalui Belanja Langsung dan Belanja Tidak Langsung.

Dari hasil perhitungan didapatkan bahwa pengaruh total Dana Perimbangan Terdahap Pertumbuhan Ekonomi Melalui Belanja Langsung dan Belanja Tidak Langsung adalah sebesar -0,173 artinya Dana Perimbangan berpengaruh Negatif terhadap Pertumbuhan Ekonomi melalui belanja langsung dan belanja tidak langsung. Hali ini tidak sesuai dengan hipotesis dalam penelitian ini. 


\section{DAFTAR PUSTAKA}

Abdullah, Syukriy dan Halim Abdul, 2004. "Pengaruh Dana Alokasi Umum (DAU) dan Pendapatan Asli Daerah (PAD) terhadap Belanja Pemerintah Daerah: Studi Kasus Kabupaten/ Kota di Jawa dan Bali”

Adi, Hari Priyo. 2006. Hubungan antara pertumbuhan ekonomi daerah belanja pembangunan dan pendapatan asli daerah studi pada Kab/Kota se Jawa bali. SNA VI. Padang. (diakses tanggal 06 Agustus 2015)

Akhmad Imam Amrozi (2013), "Pengaruh Dana Alokasi Umum ( DAU) Dan Pendapatan Asli Daerah (PAD) Terhadap Alokasi Belanja Pemerintah Daerah" Jurnal Ilmu dan Riset Akuntansi, Sekolah Tinggi Ilmu Ekonomi Indonesia (STIESIA) Surabaya.

Anasmen, 2009. Pengaruh Belanja Modal Pemerintah terhadap pertumbuhan ekonomidi provinsi sumatera barat 2000-2006. tesis universitas indonesia (dipublikasikan).

Ardhani, Pungky. 2011. Pengaruh Pertumbuhan Ekonomi, Pendapatan Asli Daerah, Dana Alokasi Umum, Dan Dana Alokasi Khusus Terhadap Pengalokasian Anggaran Belanja Modal (Studi Pada Pemerintah Kabupaten/Kota Di Jawa Tengah). Skripsi (dipublikasikan). Semarang: Universitas Diponegoro.

Arif, Bachtiar dan Muchlis, Iskandar. 2002. Akuntansi Pemerintahan. Salemba Empat. Jakarta.

Badudu. Solihin, 2006, Otonomi Daerah dan Sektor Pelayanan Publik,Bumi Aksara Jakarta.

Brata, Aloysius Gunadi. 2004. Komposisi Penerimaan Sektor Publik dan Pertumbuhan Ekonomi Regional. Lembaga Penelitian Universitas Atma Jaya Yogyakarta.

Christy, Fhino Andrea dan Adi, Priyo Hari. 2009. "Hubungan antara DAU, Belanja Modal dan Kualitas Pembangunan Manusia". (diunduh dari http://priyohari.files.wordpress.com/2010/01/hubungan antar dau-bmipm_revisi. pdf) diakses pada tanggal 20 November 2015.

Deliarnov. (2010). Perkembangan Pemikiran Ekonomi. Jakarta: PT. Raja Grafindo Persada

Erlina. 2011. Metodologi Penelitian. USU Press. Medan

Erlina dan Rasdianto. 2013. Akuntansi Keuangan Daerah Berbasis Akrual. Medan.

Ghozali, Imam. 2006. Analisis Multivariat dengan SPSS. Badan Penerbit Universitas Diponegoro. Semarang.

Gunantara, Putu Candra \& Dwirandra, A. A. N. B. (2014). Pengaruh Pendapatan Asli Daerah dan Dana Alokasi Umum pada Pertumbuhan Ekonomi dengan Belanja Modal sebagai Variabel Pemoderasi di Bali. E-Jurnal Akuntansi Universitas Udayana 7.3 (2014): 529-546, ISSN: 23028556

Guntur Hendriwiyanto. 2012. Pengaruh Pendapatan Daerah Terhadap Pertumbuhan Ekonomi Dengan Belanja Modal Sebagai Variabel Mediasi di 38 pemerintah kabupaten/kota di Provinsi Jawa Timur. (www.distrodoc.com/278137. diakses tanggal 31 Agustus 2015)

Halim, Abdul. 2005. Kajian tentang Keuangan Daerah Pemerintah Kota Malang. Tesis. Malang.

Hamzah, Ardi. 2007. Analisa Kinerja Keuangan terhadap Pertumbuhan Ekonomi, Penganggaran dan Kemiskinan. Tesis. Medan (diakses tanggal 13 September 2015).

Harahap, Riva Ubar. 2010.”Pengaruh Dana Alokasi Umum, Dana Alokasi

Khusus, dan Dana Bagi Hasil Terhadap Indeks Pembangunan Manusia padaKabupaten/Kota Provinsi Sumatera Utara" (Tesis). Medan: Universitas Sumatera Utara.

Harianto, David dan Hari Adi,2007. Hubungan antara Dana alokasi Umum, Belanja Modal, Pendptan Asli Daerah dan Pendapatan perkapita. Simposium Nasional Akuntansi X. Makassar. 
Hendarmin. 2012. Pengaruh Belanja Modal Pemerintah Daerah dan Investasi Swasta Terhadap Pertumbuhan Ekonomi, Kesempatan Kerja dan Kesejahteraan Masyarakat di Kabupaten/Kota Provinsi Kalimantan Barat. Jurnal EKSOS. Politeknik Negeri Pontianak.

I Gede Dwi Purnama Putra 2012 "Pengaruh belanja langsung dan belanja tidak langsung Terhadap pertumbuhan ekonomi di kabupaten Badung", Jurusan Ekonomi Pembangunan Fakultas Ekonomi Universitas Udayana

Indraningrum, Try, 2011. "Pengaruh Pendapatan Asli Daerah (PAD) dan Dana Alokasi Umum (DAU) Terhadap Belanja Langsung (Studi Pada Pemerintah Daerah Kabupaten/Kota di Provinsi Jawa Tengah", Universitas Diponegoro Fakultas Ekonomi dan Bisnis, Semarang.

Irma Syafitri (2009) Pengaruh Pertumbuhan Ekonomi, Pendapatan Asli Daerah, dan Dana Alokasi khusus terhadap Pengalokasian Anggaran Belanja Modal pada Pemerintahan Kabupaten/Kota di Propinsi Sumatera Utara Tesis. Universitas Sumatera Utara

Ismi Rizky Fitrianti dan Suryo Pratolo, 2009 Pengaruh Pendapatan Asli Daerah dan Belanja Pembangunan Terhadap Rasio Kemandirian dan Pertumbuhan Ekonomi, Studi pada Kota, Kabupaten dan Propinsi di DIY, Makalah dalam Konferensi Penelitian Keuangan Sektor Publik II, Bidakara.

Jhingan, M.L. Ekonomi Pembangunan dan Perencanaan. Rajawali Pers, Jakarta, 2004

Jonathan Sarwono, Metode Penelitian Kuantitatif \& Kualitatif, (Yogyakarta; Graha Ilmu, 2006)

Jones, Charles O. 1977. An Introduction to the Study of Public Policy. 2nd. Ed. North Scituate, MA: Duxbury Press.

1996. Pengantar Kebijakan Publik (Public Policy. Terjemahan Ricky Ismanto. Jakarta : Penerbit PT RajaGrafmdo Persada.

Kusnandar, Dodik Siswantoro. 2012. Pengaruh Dana Alokasi Umum, Pendapatan Asli Daerah, Sisa Lebih Pembiayaan Anggaran dan Luas Wilayah terhadap Belanja Modal. Universitas Indonesia. Jakarta.

Lestari, Tri, 2010. "Pengaruh Pendapatan Asli Daerah (PAD), Dana Alokasi Umum (DAU) dan Dana Bagi Hasil (DBH) Terhadap Belanja Langsung Pada Pemerintahan Kabupaten/Kota di Provinsi Jambi", Skripsi Universitas Sumatera Utara Fakultas Ekonomi, Medan.

Madjidi, N. 1997. Anggaran Pembangunan dan Ketimpangan Ekonomi antar Daerah. Prisma, LP3S.

Mahmudi, 2009, Manajemen Keuangan Daerah, Penerbit Erlangga, Yogyakarta.

Mamesa,DJ. 1995 "Sistem Administrasi Keuangan Daerah", Jakarta, Gramedia Pustaka Utama

Mangkoesoebroto, Gurito 1993: Ekonomi Publik, Edisi ke-3, Cetak ke-1, Penerbit BPFE, Yogyakarta.

Mardiasmo.2002. Otonomi Daerah sebagai upaya memperkokoh basis perekonomian daerah. jurnal ekonomi rakyat. artikel Th I no. 4 Juni 2002. Jakarta. Diakses dari www.ekonomirakyat.org/edidi4artikel 3.htm. 12/12/2015.

Masdjojo, Gregorius N. Dan Sukartono. 2009. Pengaruh Pendapatan Asli Daerah dan Dana Perimbangan Terhadap Belanja Daerah serta Analisis Flypaper Effect Kabupaten/Kota di Jawa Tengah Tahun 2006-2008. Jurnal TEMA (Telaah Manajemen). Universitas Islam Labuhan Batu.

Muis, Noni Hilwa. 2012. Pengaruh Dana Alokasi Umum dan Dana Alokasi Khusus terhadap Pertumbuhan Ekonomi dan Belanja Modal sebagai Variabel Intervening pada Kab/Kota di Provinsi Sumatera Utara.Tesis. Medan.

Mulya Zulfan (2016) "Pengaruh Dana Alokasi Umum (Dau) Terhadap Belanja Langsung Dan Belanja Tidak Langsung Pada Kabupaten/Kota Di Aceh" Skripsi Fakultas Ekonomi 
Universitas

Syiah

Kuala

Darussalam

Banda

Aceh., http://etd.unsyiah.ac.id/index.php?p=show_detail\&id=19394 diakses pada tanggal 20 Juni 2016.

Ni Komang Ayuk Sumartini : 2014). Pengaruh PAD dan DAU Terhadap Pertumbuhan Ekonomi melalui Belanja Modal di Provinsi Bali. E-Jurnal EP Universitas Udayana.

Ningsih, Efrida, Syamsul Amar dan Idris. 2013. Analisis Pertumbuhan Ekonomi, Konsumsi dan Tabungan di Sumatera Barat. Jurnal Kajian Ekonomi, Volume 1 Nomor 2.

Noor, Hendry Faisal. 2006, Ekonomi Publik, Ekonomi Untuk Kesejahteraan Rakyat, Akademia Permata, Padang.

Nurjoni. "Outlook Pembangunan Infrastruktur 2008, Mengguyur Dana, Menggapai Asa". (2008). http://www.madani-ri.com. (diakses tanggal 24 Oktober 2015).

Panjaitan, Alben Nuradi. 2011. Pengaruh Tax Effort, Pertumbuhan Belanja Modal dan Pendapatan Asli Daerah terhadap Pertumbuhan Ekonomi pada Kab/Kota di Sumatera Utara. Tesis. Medan. (diakses tanggal 21 September 2015).

Parsiyo dan Widya Iswara Madya. 2013. Indikator Keberhasilan Pembangunan. PPMKP Bogor, Jawa Barat.

Peraturan Pemerintah Nomor 104 Tahun 2000 Tentang pembagian DAU.

Priyatno, Dwi. 2008. Mandiri Belajar SPSS. MediaKom.Yogyakarta.

Pujiati, Amin. 2006. Analisis Pertumbuhan Ekonomi di Karesidenan Semarang Era Desentralisasi Fiskal. Jurnal Ekonomi Pembangunan. Universitas Muhammadiyah Surakarta.

Rahman, Herlina. 2005. Pendapatan Asli Daerah, (http://www. negara hukum.com/hukum/pendapatan-asli-daerah.html, diakses 21 November 2015).

Ramzuhri. 2008. Pengaruh Pertumbuhan Belanja Modal terhadap Perumbuhan Ekonomi pada Kabupaten di Sumut. Tesis. Medan. (diakses tanggal 21 September 2015)

Riduwan, 2007. Rumus dan Data dalam analisis Statistika. Bandung; Alfabeta.

Saad, W. dan Kamel Kalakech, 2009. The Nature of Government Expenditure and its Impact on Sustainable Economic Growth. Middle Eastern Finance and Economics. Vol. 1, No. 4. Hal: 3947.

Saidah, Nur. 2010. Analisis Pengaruh Belanja Pemerintah Daerah terhadap Pertumbuhan Ekonomi Kabupaten Tertinggal [Skripsi]. Institut Pertanian Bogor, Bogor.

Santosa, Budi. 2013. Pengaruh Pendapatan Asli Daerah dan Dana Perimbangan Daerah terhadap Pertumbuhan, Pengangguran, dan Kemiskinan 33 Provinsi di Indonesia. Jurnal Keuangan dan Bisnis. Universitas Trisakti Jakarta.

Santoso, Singgih (2012). Aplikasi SPSS pada Statisyik Parametrik Penerbit. Elex Media Komputindo

Setiyawati, Anis dan Ardi Hamzah. 2007. Analisis Pengaruh PAD, DAU, DAK, dan Belanja Pembangunan Terhadap Pertumbuhan Ekonomi, Kemiskinan, dan Pengangguran : Pendekatan Analisis Jalur, Jurnal Akuntansi dan Keuangan Indonesia, Volume 4 Nomor 2 Halaman 211228.

Simanjuntak, 2001. Analisis pengaruh PAD terhadap pertumbuhan ekonomi di Kabupaten Labuhan Batu. Tesis. Medan. (diakses tanggal 17Oktober 2015) . Tesis. Medan.

Sitaniapessy, Harry A. 2013. Pengaruh Pengeluaran Pemerintah Terhadap PDRB dan PAD. Jurnal Economica Vol.9 No.1, April 2004.

Sodik, Jamzani. 2007. Pengeluaran Pemerintah dan Pertumbuhan Ekonomi Regional (Studi Kasus Data Panel di Indonesia). Jurnal Ekonomi Pembangunan. Universitas Muhammadiyah Surakarta. 
Sukirno, Sadono. 1996. Makro Ekonomi Edisi Ke - 2. Jakarta. Erlangga.

Sukirno, Sadono. 2013. Makro Ekonomi Teori Pengantar, Edisi Ke - 3. Cetak ke-22, Penerbit PT.Rajagrafindo Persada, Jakarta.

Suliyanto. 2011, "Ekonomika Terapan: Teori dan Aplikasi dengan SPSS. Penerbit Andi. Yogyakarta.

Tarmidzi ,2014. Gemuk Aparatur, Kurus Pubblik. Refleksi diakses (diakses tanggal 10 oktober 2015).

Walidi. 2009. Pengaruh Dana Alokasi Umum terhadap Pendapatan Perkapita, Belanja Modal sebagai Variabel Intervening (Studi Kasus di Provinsi Sumatera Utara). Tesis. Sekolah Pascasarjana Universitas Sumatera Utara.

Wandira, Gugus Arbie. 2013. Pengaruh PAD, DAU, DAK, dan DBH terhadap pengalokasian belanja modal. Accounting Analysis Journal. Universitas Negeri Semarang.

Warsito (2001:128) , Herlina Rahman (2005:38), (Mamesa, 1995:30) dalam College Journal, PendapatanAsliDaerah (PAD), https://primalifejournal.wordpress.com/2013/03/26/pendapatanasli-daerah-pad/ diakses pada tanggal 20 November 2015

www. Djpk. Depkeu. go. id. (diakses tanggal 16 September 2015).

www.bps.go.id (diakses tanggal 16 September 2015)..

Yudhoyono, Susilo Bambang. 2011. Pidato kenegaraan Presiden Susilo Bambang Yudhoyono (SBY) di Gedung DPR/MPR. ttps://www.facebook.com/notes / liputan 6lovers / inilah - pidato kenegaraan - presiden - susilo - bambang - yudhoyono - sby -didungdprmpr / 274076729274524. (Diakses tanggal 20 November 2014). 